\title{
The impact of early diagnosis on the prognosis of extranodal NK/T-cell lymphoma with massive lung involvement: a case report
}

Tomohiro Yabushita', Satoshi Yoshioka ${ }^{1 *}$, Takeru Furumiya', Momoko Nakamura', Daisuke Yamashita², Yukihiro Imai $^{2}$ and Takayuki Ishikawa ${ }^{1}$

\begin{abstract}
Background: Pulmonary non-Hodgkin lymphoma (NHL) is rare. The most frequent subtype of pulmonary NHL is low-grade B-cell lymphoma, such as lymphoma of mucosa-associated lymphoma tissue. Extranodal natural killer cell/T-cell lymphoma, nasal type (ENKL) is characterized by predominant extranodal involvement and association with Epstein-Barr virus (EBV). ENKL with massive lung involvement has been infrequently reported, and its prognosis is extremely poor.

Case presentation: A 20-year-old Japanese man presented with intermittent fever lasting for 2 months. Radiological imaging demonstrated multiple nodules of uneven shape and size in both lungs. Video-assisted thoracic surgical lung biopsy showed abnormal lymphocyte infiltration, which was positive for CD3, CD56, and perforin. In situ hybridization for EBV-encoded RNA was positive. From these findings, he was diagnosed with ENKL with lung involvement. The patient was successfully treated with intensive combinational chemotherapy followed by allogeneic cord blood transplantation. He has been alive with continuous complete remission for 1 year after diagnosis.

Conclusions: Although ENKL involving the lung has been reported to have dismal outcomes, our patient showed long-term survival after intensive chemotherapy and up-front allogeneic hematopoietic transplantation. The present case highlights the importance of early diagnosis as well as allogeneic transplantation.
\end{abstract}

Keywords: Lymphoma, Lung, Extranodal NKT-cell lymphoma, Epstein-Barr virus

\section{Background}

Pulmonary non-Hodgkin lymphoma (NHL) is a rare disease representing approximately $1 \%$ of all NHLs and $0.5-1.0 \%$ of all pulmonary malignancies [1]. The majority of pulmonary NHLs are of mature B-cell lineage and most are lymphomas of mucosa-associated lymphoma tissue, characterized by an indolent clinical course and good treatment response. In contrast, mature T-cell or natural killer (NK) cell lymphomas involving the lung are less common, and usually have an aggressive clinical course [2].

\footnotetext{
* Correspondence: satoseay@kcho.jp

${ }^{1}$ Department of Hematology, Kobe City Medical Center General Hospital,

2-1-1, Minatojima-Minamimachi, Chuo-ku, Kobe 650-0047, Japan

Full list of author information is available at the end of the article
}

Extranodal NK/T-cell lymphoma, nasal type (ENKL) is a subtype associated with Epstein-Barr virus (EBV) infection and commonly involves the upper respiratory tract, such as the nasal cavity, nasopharynx, and paranasal sinuses [3]. In previous reports, approximately 1423\% of ENKLs occurred in extranasal sites: the skin, soft tissue, gastrointestinal tract, and testis [4-7]. Pulmonary involvement of ENKL (pulmonary ENKL) is extremely rare. Here, we report a young Japanese man with pulmonary ENKL who was successfully treated with intensive combination chemotherapy and cord blood transplantation $(\mathrm{CBT})$.

(c) The Author(s). 2019 Open Access This article is distributed under the terms of the Creative Commons Attribution 4.0 International License (http://creativecommons.org/licenses/by/4.0/), which permits unrestricted use, distribution, and reproduction in any medium, provided you give appropriate credit to the original author(s) and the source, provide a link to the Creative Commons license, and indicate if changes were made. The Creative Commons Public Domain Dedication waiver (http://creativecommons.org/publicdomain/zero/1.0/) applies to the data made available in this article, unless otherwise stated. 


\section{Case presentation}

A 20-year-old Japanese man presented with a 2-month history of fever, night sweats, and mild weight loss. He had no rash or palpable peripheral lymphadenopathy. Laboratory tests revealed anemia (hemoglobin, $9.5 \mathrm{~g} / \mathrm{dL}$ ), leukopenia (white blood cell, $2.4 \times 10^{9} / \mathrm{L}$ ), and elevated lactate dehydrogenase $(\mathrm{LDH}, 1175 \mathrm{U} / \mathrm{L}$; normal range $120-250 \mathrm{U} / \mathrm{L})$. The EBV-DNA level was extremely high in the whole blood $\left(4.0 \times 10^{6}\right.$ copies $\left./ \mathrm{mL}\right)$. Abnormal cells were not detected in the peripheral blood (PB). Other laboratory data are shown in Table 1. Chest radiography showed bilateral pulmonary lesions predominantly in the upper lung. Computed tomography (CT) showed multiple nodules diffusely mixed with consolidation and ground-glass opacity pattern in both lungs (Fig. 1). Enlargement of the mediastinal and hilar lymph nodes and hepatosplenomegaly were also observed. Positron emission tomography (PET)/CT showed abnormal uptake of 18-fluorodeoxyglucose (FDG) in multiple lung lesions, as well as the mediastinal and hilar lymph nodes, bilateral humeral bones, lumbar spine, liver, and spleen. The maximum standardized uptake value (SUVmax) of lung nodules (median, 4.7; range, 3.2-9.6) was lower than that of hilar lymph nodes (median, 16.7; range, 7.5-18.3) (Fig. 2).

Video-assisted thoracoscopic surgical lung biopsy (VATS) was performed the next day. Visual inspection revealed dark purple patchy lesions on the whole lung surface, and specimens were obtained from the left S6 and $\mathrm{S} 1+2$. Pathological examination showed large-sized atypical cell infiltration localized mainly in the lumina and perivascular areas of the distended vessels beneath the pleura and in the pulmonary parenchyma (Fig. 3). These abnormal cells had irregularly contoured nuclei, prominent nucleoli, and narrow cytoplasm. The tumor cells were positive for cytoplasmic CD3e, CD56, and perforin, and negative for cytokeratin, CD20, and CD30 by immunohistochemistry. EBV infection was detected by in situ hybridization analysis for EBV-encoded RNA. The Ki-67 proliferation index showed $70-80 \%$ nuclear staining. T-cell receptor $\gamma$ chain rearrangement was not proven, which was consistent with an NK-cell origin. Based on these findings, he was diagnosed with ENKL (Stage IV). The bone marrow was normocellular with an increase in activated histiocytes containing engulfed red blood cells, nuclear debris, and platelets, but no neoplastic cell infiltration was observed. This finding was compatible with hemophagocytic lymphohistiocytosis (HLH).

One week after admission, he received combination SMILE regimen chemotherapy (dexamethasone, methotrexate, ifosfamide, l-asparaginase, and etoposide). After two cycles of SMILE, complete remission (CR) was confirmed by FDG-PET/CT, and EBV-DNA became undetectable in the PB. Subsequently, he received a single unit CBT after myeloablative conditioning of cyclophosphamide $(120 \mathrm{mg} / \mathrm{kg})$ plus $12 \mathrm{~Gy}$ total-body irradiation. Graft-versus-host disease (GVHD) prophylaxis consisted of tacrolimus and mycophenolate mofetil. On day 16, he achieved successful neutrophil engraftment. On day 21, he developed biopsy-proven gastro-intestinal acute GVHD (grade II), which gradually improved with prednisolone at doses of $0.5 \mathrm{mg} / \mathrm{kg}$ daily. On day 88 , he was discharged in complete remission with no other major complication. Four months later, he developed mild

Table 1 Laboratory Data at the time of his admission

\begin{tabular}{|c|c|c|c|c|c|}
\hline \multicolumn{2}{|c|}{ Complete blood counts } & \multicolumn{2}{|c|}{ Biochemistry } & \multicolumn{2}{|c|}{ Viral and Fungal Markers } \\
\hline WBC & $2400 / \mu \mathrm{L}$ & $\mathrm{TP}$ & $6.1 \mathrm{~g} / \mathrm{dL}$ & $\mathrm{HBs} \mathrm{Ag}$ & $0.011 \mathrm{U} / \mathrm{mL}$ \\
\hline Neut. & $63.0 \%$ & Alb & $3.4 \mathrm{~g} / \mathrm{dL}$ & $\mathrm{HBs} A b$ & $0.0 \mathrm{mlU} / \mathrm{mL}$ \\
\hline Lymph. & $22.0 \%$ & AST & $59 \mathrm{U} / \mathrm{L}$ & $\lg M-H B c A b$ & $0.1 \mathrm{~S} / \mathrm{CO}$ \\
\hline Mono. & $15.0 \%$ & $\mathrm{ALT}$ & $58 \mathrm{U} / \mathrm{L}$ & HCVAb & $0.1 \mathrm{~S} / \mathrm{CO}$ \\
\hline Abnormal lymph. & $0.0 \%$ & LDH & $1181 \mathrm{U} / \mathrm{L}$ & $\mathrm{HIV} 1 / 2 \mathrm{Ab}$ & $0.1 \mathrm{~S} / \mathrm{CO}$ \\
\hline $\mathrm{RBC}$ & $322 \times 10^{4} / \mu \mathrm{L}$ & T-bil & $0.6 \mathrm{mg} / \mathrm{dL}$ & EBV-VCA IgM & $(-)$ \\
\hline $\mathrm{Hb}$ & $10.2 \mathrm{~g} / \mathrm{dL}$ & BUN & $9.6 \mathrm{mg} / \mathrm{dL}$ & EBV-VCA lgG & $(+)$ \\
\hline Plt & $14.1 \times 10^{4} / \mu \mathrm{L}$ & Cre & $0.71 \mathrm{mg} / \mathrm{dL}$ & EBV-EBNA & $(+)$ \\
\hline Coagulation tests & & $\mathrm{Na}$ & 137 mEq/L & EBV-DNA & $4,000,000$ copy $/ \mathrm{mL}$ \\
\hline PT-INR & 1.21 & K & $3.8 \mathrm{mEq} / \mathrm{L}$ & & \\
\hline APTT & $45.8 \mathrm{~s}$ & CRP & $1.01 \mathrm{mg} / \mathrm{dL}$ & & \\
\hline Fib & $523 \mathrm{mg} / \mathrm{dL}$ & SIL-2R & $4863 \mathrm{U} / \mathrm{mL}$ & & \\
\hline D-dimer & $7.86 \mu / \mathrm{mL}$ & ferritin & $2926 \mathrm{ng} / \mathrm{mL}$ & & \\
\hline
\end{tabular}

WBC white blood cells, Neut neutrophils, Lymph lymphocytes, Mono monocytes, Abnormal lymph Abnormal lymphocytes, RBC Red blood cells, Hb hemoglobin, Plt platelet, $P T$ prothrombin time, APTT activated partial thromboplastin time, Fib fibrinogen, $T P$ total protein, Alb albumin, $A S T$ asparate aminotranferase, $A L T$ alanine aminotransferase, $L D H$ lactate dehydrogenase, $T$-bil total bilirubin, $B U N$ blood urea nitrogen, $C r e$ creatinine, $C R P C$-reactive protein, sIL-2R soluble IL-2 receptor, $A b$ antibody, $A g$ antigen, $H B$ hepatitis $B$ virus, $H C V$ hepatitis $C$ virus, HIV human immunodeficiency virus, EBV Epstein-Barr virus VCA; viral capsid antigen, EBNA EBV nuclear antigen 


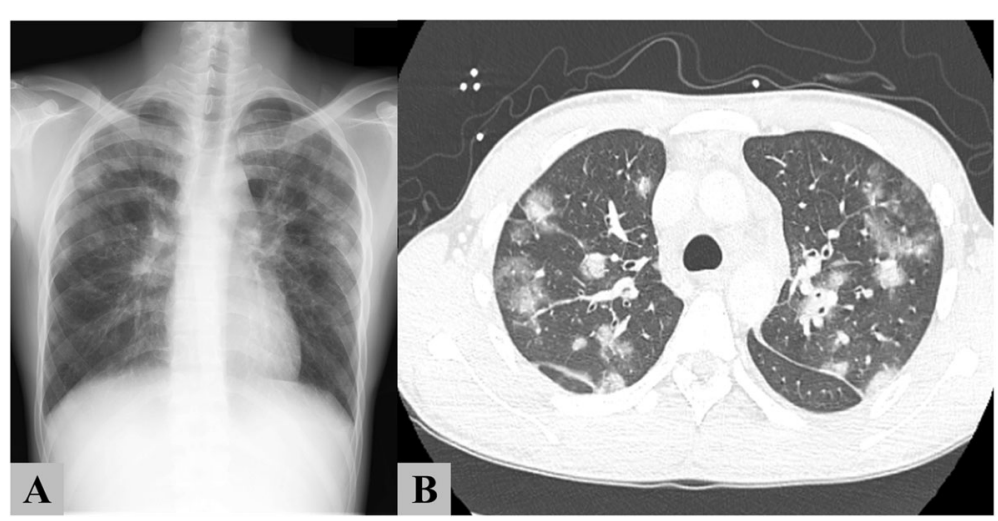

Fig. 1 Radiological imaging on admission. Chest computed tomography revealed multiple nodules in both lungs that showed diffusely mixed with consolidation and ground-glass opacity pattern. (a; coronal section, $\mathbf{b}$; horizontal section)

cutaneous chronic GVHD limited to the head and neck, which could be managed with topical steroids. He has been alive with continuous CR for 1 year after diagnosis.

\section{Discussions and conclusions}

ENKL is a rare type of lymphoma associated with EBV infection that most commonly involves the upper aerodigestive mucosa and skin. Although localized ENKL has a better prognosis when treated with concurrent chemoradiotherapy [8], advanced ENKL often displays a fulminant clinical course with very poor prognosis. Therefore, especially in advanced ENKL, a delay in diagnosis could provoke multiple organ dysfunction and make treatment difficult. In our case, surgical lung biopsy contributed to the rapid and precise diagnosis of ENKL, which resulted in maximal therapeutic efficacy.

ENKL involving the lung is rare, and only 14 cases of ENKL with massive pulmonary involvement have been reported in the English literature [2, 9-16]. The diagnosis of pulmonary ENKL is often difficult because of the nonspecific clinical symptoms and radiological findings. In previously published reports, the major initial symptoms of this disorder were fever $(n=12)$ and cough $(n=10)$. Moreover, the common CT findings were multiple nodules in both lungs $(n=9)$, consolidation $(n=4)$, bronchial or mediastinal involvement $(n=3)$, pleural effusion $(n=3)$, and a single lesion in one lung $(n=2)$. Although laboratory data were not available in all cases $(n=6)$, pancytopenia

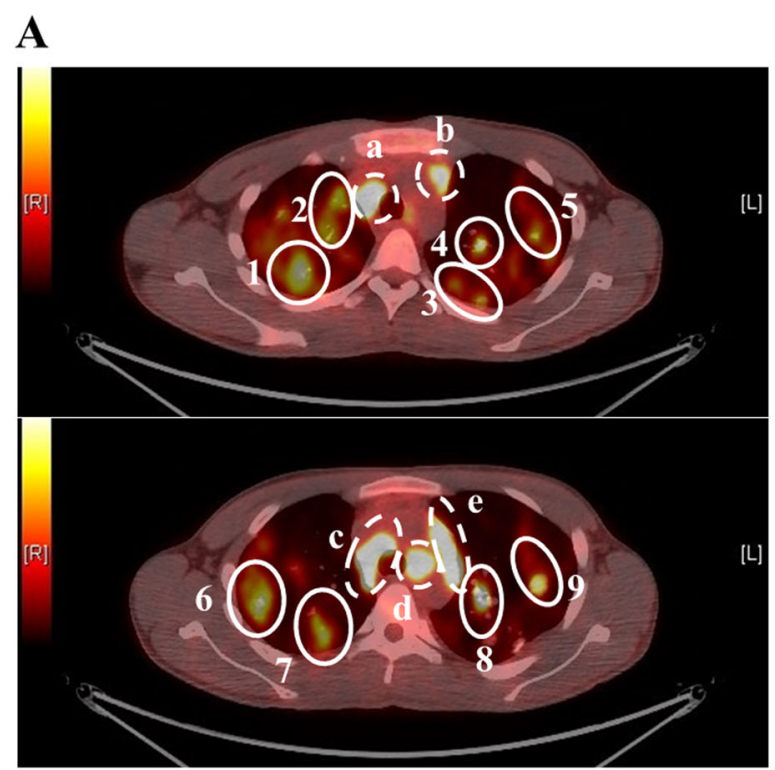

B

\begin{tabular}{cc}
\hline Lesion & SUVmax \\
\hline Lung nodule & \\
1 & 4.8 \\
2 & 4.1 \\
3 & 3.2 \\
4 & 4.9 \\
5 & 3.8 \\
6 & 4.7 \\
7 & 4.7 \\
8 & 9.6 \\
9 & 4.7
\end{tabular}

Lymph node

\begin{tabular}{cc}
$\mathrm{a}$ & 16.7 \\
$\mathrm{~b}$ & 7.5 \\
$\mathrm{c}$ & 16.9 \\
$\mathrm{~d}$ & 18.3 \\
$\mathrm{e}$ & 12.1 \\
\hline
\end{tabular}

Fig. 2 The axial view of FDG-PET/CT scan on diagnosis. (A) PET/CT scan shows intense FDG uptake in bilateral lung masses and the mediastinal and hilar lymph nodes. Each lung nodule is surrounded by a solid-line circle (1-9). Each mediastinal lymph node is surrounded by a dotted line circle (a-e). (B) The maximum standardized uptake values (SUVmax) of the lesions are shown here 


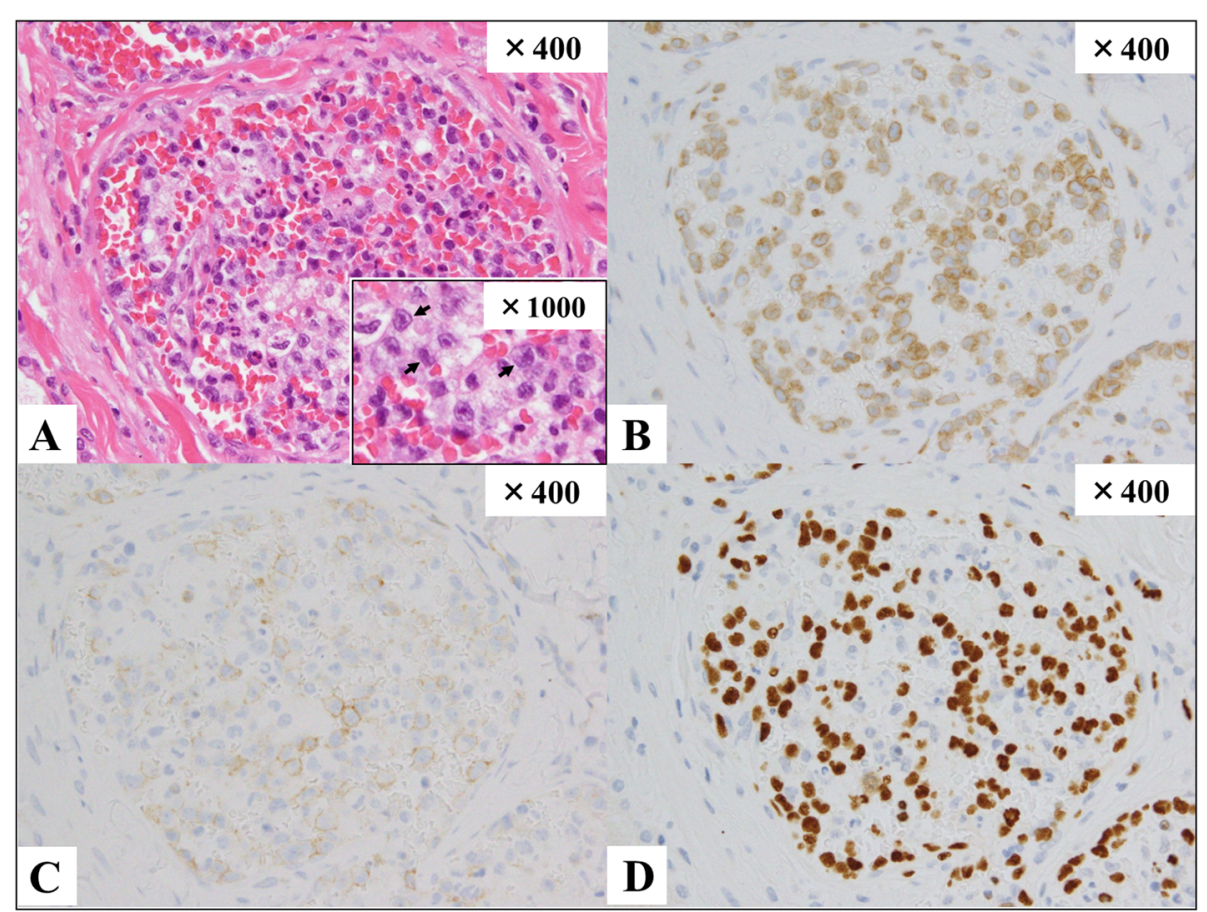

Fig. 3. Pathological findings of the lung biopsy. Atypical large-sized lymphoid cells filled several distended vessels beneath the pleura and in the pulmonary parenchyma (hematoxylin and eosin; $\times 400$ (A)). The neoplastic cells had irregular nuclear contours, prominent nucleoli, and narrow cytoplasm (black arrow), described in a partially expanded image on the lower right field. Abnormal mitosis was prominent in the cells. The moderate inflammatory response caused mainly by plasma cells was seen in perivascular areas, but no fibrin thrombi or necrosis was observed. The alveolar epithelial cells showed reactive nuclear enlargement. The tumor cells in pulmonary arterioles were positive for cytoplasmic CD3 (B), CD56 (C), perforin, and Ki-96 (not shown). In situ hybridization analysis for Epstein-Barr virus-encoded messenger RNA was positive (D).

$(n=4)$ and elevated LDH (median, $498 \mathrm{U} / \mathrm{L}$; range 135-1192 IU/L) were commonly observed.

Lung biopsy is required for definite diagnosis of ENKL mainly involving the lungs. Eleven of the 14 patients were diagnosed using lung biopsy, including transbronchial lung biopsy (TBLB; $\mathrm{n}=2)$, CT-guided biopsy $(n=2)$, surgical biopsy $(n=1)$, and unspecified core biopsy $(n=6)$. The other 3 patients were diagnosed at autopsy despite repeated antemortem biopsies. Specimens obtained by TBLB or CT-guided biopsy are often inappropriate because of their small-sized sampling. In contrast, surgical biopsy enables a sufficient amount of specimen for precise diagnosis. Therefore, the surgical approach should be considered as a helpful diagnostic method for ENKL before rapid exacerbation, especially when ENKL is suspected on the basis of clinical features. In the present case, considering the complication of $\mathrm{HLH}$ and the highly elevated level of EBV-DNA, we included ENKL in the differential diagnosis list, and chose surgical biopsy as a diagnostic procedure before rapid exacerbation.

Some ENKL cases are complicated by lymphoma-associated HLH, which usually presents with persistent high fever, pancytopenia, hepatosplenomegaly, or elevated levels of soluble interleukin-2 receptor or ferritin. Approximately half of the cases of lymphoma-associated
HLH have been reported to be correlated with EBV-associated lymphoid malignancies, such as ENKL [17]. In addition, it is well known that almost all ENKL cases show positive EBV-DNA in their $\mathrm{PB}$, but not in the normal control. EBV-DNA detection using $\mathrm{PB}$ samples is very helpful for diagnosis.

The prognosis of advanced ENKL is very poor; overall survival (OS) at 5 years for advanced ENKL has been reported to be approximately 25\% [8]. Pulmonary ENKL usually has a fatal outcome $[18,19]$. Eight of the 14 patients described in the literature were treated with chemotherapy. One received autologous hematopoietic stem cell transplantation followed by high-dose chemotherapy. However, all died of disease progression regardless of intensive treatment. The median OS in 12 evaluable patients was 2 months (range, 1 week to 7 months). Recently, combinational chemotherapy containing L-asparaginase (the SMILE regimen) has been reported to be effective for ENKL compared to the conventional anthracycline-based regimen, such as CHOP (cyclophosphamide, doxorubicin, vincristine, and prednisone) [20]. In several guidelines, subsequent hematopoietic stem cell transplantation (HSCT) is recommended for patients with advanced ENKL achieving CR after induction chemotherapy because of its poor prognosis $[21,22]$. We determined to perform 
allogeneic (allo-) HSCT for this patient after achieving CR with two courses of the SMILE regimen, because the extremely poor prognosis of pulmonary ENKL was estimated from the above literature review. Since neither related nor unrelated HLA-matched donor was found, we selected cord blood donor. He has been alive with continuous $\mathrm{CR}$ for 1 year after diagnosis. However, there is no clear evidence to determine whether autologous (auto-) or allo-HSCT is preferred for advanced ENKL. Yim et al. reported the outcome of upfront auto-HSCT for ENKL. Patients with advanced disease had significantly worse prognosis than those with limited disease: 3-year progression free survival (PFS), $40.1 \%$ versus $64.5 \%, p=0.017$; OS, $52.3 \%$ versus $67.6 \%, p=0.048$ [23]. In contrast, allo-HSCT for ENKL has been evaluated only by small retrospective studies: OS rates were 34-57\% [24-26]. In a retrospective nationwide survey of auto-HSCT and allo-SCT for Japanese patients with ENKL, the 2-year OS in auto-HSCT group was superior compared to allo-SCT group: $69 \%$ versus $41 \%, p=0.002$. However, when adjusted by advanced stage, disease status, and performance status at transplant, there was no significant difference of 2-year OS between both transplant procedures, because the allo-HSCT group included more patients with advanced stage and refractory disease condition [27]. Allo-SCT could be one of the curative options for some patients with advanced ENKL. In general, the primary indication for allo-HSCT should be cautiously considered in each individual case.

In summary, we described a rare case of a pulmonary ENKL in a 20-year-old man who was successfully diagnosed using early surgical biopsy and treated with intensive multi-agent chemotherapy and up-front CBT, and he has survived more than 1 year with no relapse. In the present case, VATS was helpful for prompt diagnosis and successful treatment. Collection of sufficient specimen with any invasive procedure is crucial for diagnosis of pulmonary aggressive lymphoma like ENKL.

\section{Abbreviations \\ CBT: cord blood transplantation; CHOP: cyclophosphamide, doxorubicin, vincristine and prednisone; CR: complete response; CT: computed tomography; EBV: Epstein-Barr virus; ENKL: extranodal NK/T-cell lymphoma, nasal type; FDG: 18-fluorodeoxyglucose; HLH: hemophagocytic lymphohistiocytosis; LDH: lactate dehydrogenase; NHL: non-Hodgkin lymphoma; NK: natural killer; OS: overall survival; PB: peripheral blood; PET: positron emission tomography; SMILE: dexamethasone, methotrexate, ifosfamide, l-asparaginase, and etoposide; TBLB: transbronchial lung biopsy; VATS: video-assisted thoracoscopic surgical lung biopsy}

\section{Acknowledgements}

We thank Mr. Hayato Maruoka, Mr. Kaoru Sueoka, Mr. Masahiro Yoshida, Ms. Yukiko Yano, Ms. Eiko Yamashita, Mr. Kazuyuki Ueno, and Ms. Kyoko Tanaka from the Department of Clinical Laboratory, Kobe City Medical Center General Hospital for their technical assistance.

\section{Funding}

We have not received any source of support in the form of grants, equipment, or drugs.

\section{Availability of data and materials}

The data used and analyzed during the current study are available from the corresponding author on reasonable request.

\section{Authors' contributions}

T.Y., S.Y., T.F., and M.N. treated the patient as the attending physician; D.Y. and Y.I. performed the histological examination of the lung; T.Y., S.Y., and T.I. wrote the manuscript; and all authors revised and approved the manuscript.

\section{Ethics approval and consent to participate}

This case report complied with the Declaration of Helsinki and was approved by the Ethical Committee of Kobe City Medical Center General Hospital. (Approval No. zn171210).

\section{Consent for publication}

Written informed consent for publication was obtained from the patient, according to the governance that the Ethical Committee of Kobe City Medical Center General Hospital approved.

\section{Competing interests}

The authors declare that they have no competing interests.

\section{Publisher's Note}

Springer Nature remains neutral with regard to jurisdictional claims in published maps and institutional affiliations.

\section{Author details}

'Department of Hematology, Kobe City Medical Center General Hospital, 2-1-1, Minatojima-Minamimachi, Chuo-ku, Kobe 650-0047, Japan.

${ }^{2}$ Department of Pathology, Kobe City Medical Center General Hospital, 2-1-1, Minatojima-Minamimachi, Chuo-ku, Kobe 650-0047, Japan.

Received: 20 December 2017 Accepted: 14 February 2019

Published online: 21 February 2019

\section{References}

1. Cadranel J, Wislez M, Antoine M. Primary pulmonary lymphoma. Eur Respir J. 2002;20:750-62

2. Laohaburanakit $P$, Hardin KA. NK/T cell lymphoma of the lung: a case report and review of literature. Thorax. 2006;61:267-70

3. Campo E, Swerdlow SH, Harris NL, Pileri S, Stein H, Jaffe ES. The 2008 WHO classification of lymphoid neoplasms and beyond: evolving concepts and practical applications. Blood. 2011;117:5019-32.

4. Shet $T$, Suryawanshi $P$, Epari $S$, Sengar M, Rangarajan V, Menon H, et al. Extranodal natural killer/T cell lymphomas with extranasal disease in nonendemic regions are disseminated or have nasal primary: a study of 84 cases from India. Leuk Lymphoma. 2014;55:2748-53.

5. Li S, Feng X, Li T, Zhang S, Zuo Z, Lin P, et al. Extranodal NK/T-cell lymphoma, nasal type: a report of 73 cases at MD Anderson Cancer Center. Am J Surg Pathol. 2013;37:14-23.

6. Gualco G, Domeny-Duarte P, Chioato L, Barber G, Natkunam Y, Bacchi CE. Clinicopathologic and molecular features of 122 Brazilian cases of nodal and extranodal NK/T-cell lymphoma, nasal type, with EBV subtyping analysis. Am J Surg Pathol. 2011;35:1195-203.

7. Chan JK, Sin VC, Wong KF, Ng CS, Tsang WY, Chan CH, et al. Nonnasal lymphoma expressing the natural killer cell marker CD56: a clinicopathologic study of 49 cases of an uncommon aggressive neoplasm. Blood. 1997:89:4501-13.

8. Yamaguchi M, Suzuki R, Oguchi M, Asano N, Amaki J, Akiba T, et al. Treatments and outcomes of patients with Extranodal natural killer/T-cell lymphoma diagnosed between 2000 and 2013: A cooperative study in Japan. J Clin Oncol. 2017;35:32-9.

9. Oshima K, Tanino Y, Sato S, Inokoshi Y, Saito J, Ishida T, et al. Primary pulmonary extranodal natural killer/T-cell lymphoma: nasal type with multiple nodules. Eur Respir J. 2012;40:795-8.

10. Morovic A, Aurer I, Dotlic S, Weisenburger DD, Nola M. NK cell lymphoma, nasal type, with massive lung involvement: a case report. J Hematop. 2010;3:19-22.

11. Liu CH, Wang HH, Perng CL, Peng CK, Chian CF, Shen CH. Primary extranodal NK/T-cell lymphoma of the lung: mimicking bronchogenic carcinoma. Thorac Cancer. 2014;5:93-6. 
12. Li Y, Damjanov I. Extranodal NK/T cell lymphoma causing cardiorespiratory failure. Case Rep Hematol. 2016;2016:2394809.

13. Lee $\mathrm{S}$, Shin B, Yoon H, Lee JY, Chon GR. A case of primary pulmonary NKTT cell lymphoma presenting as pneumonia. Respir Med Case Rep. 2015;17:1-4.

14. Lee BH, Kim SY, Kim MY, Hwang YJ, Han YH, Seo JW, et al. CT of nasal-type T/NK cell lymphoma in the lung. J Thorac Imaging. 2006;21:37-9.

15. Ding W, Wang J, Zhao S, Yang Q, Sun H, Yan J, et al. Clinicopathological study of pulmonary extranodal nature killer/T-cell lymphoma, nasal type and literature review. Pathol Res Pract. 2015;211:544-9.

16. Chien CC, Lee HS, Lin MH, Hsieh PP. Primary extranodal natural killer/T-cell lymphoma of bronchus and lung: A case report and review of literature. Thorac Cancer. 2016;7:140-4.

17. Kawa K. Epstein-Barr virus--associated diseases in humans. Int J Hematol. 2000;71:108-17.

18. Suzuki R, Suzumiya J, Yamaguchi M, Nakamura S, Kameoka J, Kojima H, et al. Prognostic factors for mature natural killer (NK) cell neoplasms: aggressive NK cell leukemia and extranodal NK cell lymphoma, nasal type. Ann Oncol. 2010;21:1032-40

19. Au WY, Weisenburger DD, Intragumtornchai T, Nakamura S, Kim WS, Sng I, et al. Clinical differences between nasal and extranasal natural killer/T-cell lymphoma: a study of 136 cases from the international peripheral T-cell lymphoma project. Blood. 2009;113:3931-7.

20. Yamaguchi M, Kwong Y-L, Kim WS, Maeda Y, Hashimoto C, Suh C, et al. Phase II study of SMILE chemotherapy for newly diagnosed stage IV, relapsed, or refractory extranodal natural killer (NK)/T-cell lymphoma, nasal type: the NK-cell tumor study group study. J Clin Oncol. 2011:29:4410-6.

21. National Comprehensive Cancer Network. NCCN Clinical Practice Guidelines in Oncology T-cell Lymphomas. version 4. 2018. (https://www.nccn.org/ professionals/physician_gls/pdf/t-cell.pdf). Accessed 2018 May 14.

22. Kharfan-Dabaja MA, Kumar A, Ayala E, Hamadani M, Reimer P, Gisselbrecht $C$, et al. Clinical practice recommendations on indication and timing of hematopoietic cell transplantation in mature T cell and NKTT cell lymphomas: an international collaborative effort on behalf of the guidelines Committee of the American Society for blood and marrow transplantation. Biol Blood Marrow Transplant. 2017;23:1826-38.

23. Yhim HY, Kim JS, Mun YC, Moon JH, Chae YS, Park Y, et al. And the consortium for improving survival of lymphoma study. Clinical outcomes and prognostic factors of up-front autologous stem cell transplantation in patients with Extranodal natural killer/T cell lymphoma. Biol Blood Marrow Transplant. 2015;21:1597-604.

24. Murashige N, Kami M, Kishi Y, Kim SW, Takeuchi M, Matsue K, et al. Allogeneic haematopoietic stem cell transplantation as a promising treatment for natural killer-cell neoplasms. Br J Haematol. 2005;130:561-7.

25. Tse E, Chan TSY, Koh LP, Chung WJ, Kim WS, Tang T, et al. Allogeneic haematopoietic SCT for natural killer/T-cell lymphoma: a multicentre analysis from the Asia lymphoma study group. Bone Marrow Transplant. 2014;49:902-6.

26. Kanate AS, DiGilio A, Ahn KW, AL Malki M, Jacobsen E, Steinberg A, et al. Allogeneic haematopoietic cell transplantation for extranodal natural killer/ T-cell lymphoma, nasal type: a CIBMTR analysis. Br J Haematol. 2017. https:// doi.org/10.1111/bjh.14879.

27. Suzuki R, Kako S, Hyo R, Izutsu K, Ito T, Shinagawa K, et al. Comparison of Autologous and Allogeneic Hematopoietic Stem Cell Transplantation for Extranodal NK/T-Cell Lymphoma, Nasal Type: Analysis of the Japan Society for Hematopoietic Cell Transplantation (JSHCT) Lymphoma Working Group. Blood 2011;118:Abstract 503.

Ready to submit your research? Choose BMC and benefit from:

- fast, convenient online submission

- thorough peer review by experienced researchers in your field

- rapid publication on acceptance

- support for research data, including large and complex data types

- gold Open Access which fosters wider collaboration and increased citations

- maximum visibility for your research: over $100 \mathrm{M}$ website views per year

At $\mathrm{BMC}$, research is always in progress.

Learn more biomedcentral.com/submissions 